\title{
Assessing social vulnerability to drought in South Africa: Policy implication for drought risk reduction
}

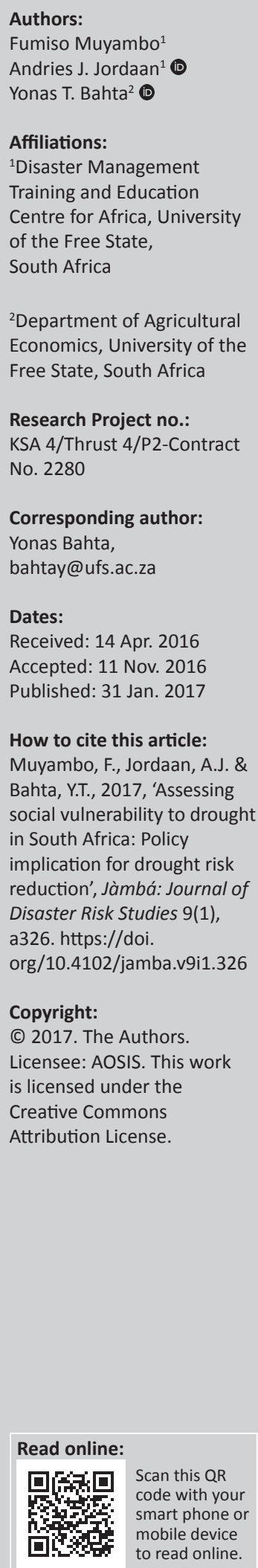

Corresponding author:

Yonas Bahta,

bahtay@ufs.ac.za

Dates:

Received: 14 Apr. 2016

Accepted: 11 Nov. 2016

Published: 31 Jan. 2017

How to cite this article:

Muyambo, F., Jordaan, A.J. \&

Bahta, Y.T., 2017, 'Assessing

social vulnerability to drought

in South Africa: Policy

implication for drought risk

reduction', Jàmbá: Journal of Disaster Risk Studies 9(1),

a326. https://doi.

org/10.4102/jamba.v9i1.326

Copyright:

(C) 2017. The Authors.

Licensee: AOSIS. This work

is licensed under the

Creative Commons

Attribution License.

Read online:

Scan this QR code with your smart phone or mobile device to read online.

The aim of this article was to assess and identify social vulnerability of communal farmers to drought in the O.R. Tambo district in the Eastern Cape province of South Africa using a survey data and social vulnerability index (SoVI). Eleven social vulnerability indicators were identified using Bogardi, Birkman and Cardona conceptual framework. The result found that an SoVI estimated for O.R. Tambo district was very high with a Likert scale of 5 for cultural values and practices, security or safety, social networks, social dependence, preparedness strategies and psychological stress attributed for the high value of social vulnerability to drought. Indigenous knowledge and education had an SoVI value of 2, which was of low vulnerability, contributing positively to resilience to drought. The study also found that government involvement in drought risk reduction is limited; as a result, the study recommends that a national, provincial and district municipalities policy on drought risk reduction and mitigation should be developed.

\section{Introduction}

Drought is not exceptional to South Africa alone. Approximately $60 \%$ of sub-Saharan Africa is considered to be susceptible to drought (Ngaka 2012). Ngaka (2012), Food and Agriculture Organization (FAO) (2013) and the Department of Rural Development and Land Reform (DRDLR 2013) concur that drought has been ranked a major concern in South Africa in terms of the total economic losses, as well as the number of people affected. Drought emergency in six provinces of South Africa affects 4 million (IRIN News 2004). O.R. Tambo district of Eastern Cape province has been reported as one of the worst drought affected districts (Gumenge 2010). According to the South African Weather Service, South Africa experienced a worst drought period in South African history since 1982. Prolonged droughts are a significant threat to the vulnerable communities of the region including O.R. Tambo district of South Africa. The Eastern Cape province including O.R. Tambo district is one of the six provinces that were declared as disaster areas in 1982-1983, 2003-2004, 2007-2008 and 2009-2010 by the National Disaster Management Centre (NDMC) (Gumenge 2010; NDMC 2016). In 2015-2016, Eastern Cape province was also declared as a drought disaster area by the Minister of Cooperative Governance and Traditional Affairs (SABC 2016). The 2015-2016 drought was a result of an extremely strong El Niño and is comparable with the 1933 and 1982 droughts in South Africa, with more than $2.7 \mathrm{~m}$ households facing water shortages across the country (The Southern Times 2016). The most severe El Niño-induced drought in decades led to the official declarations of disaster in all but two provinces in terms of the disaster Management Act, 2002 (Agri SA 2016). The drought in South Africa costs farmers' losses up to R10m (USD 689, 655.2) in 2015 ( $R=$ Rand, the South African unit of currency) (Bahta, Jordaan \& Muyambo 2016).

The recurring drought events and their associated negative impacts on the people, such as the 2003-2004 and 2009-2010 droughts which were declared disasters by the then president, Thabo Mbeki, and the Minister of the Department of Water Affairs and Forestry, Buyelwa Sonjica (IRIN News 2004; Gumenge 2010). Drought risk is based on a combination of the frequency, severity, and spatial extent of drought and the degree to which a population is vulnerable to the effects of drought (UNISDR 2005). Be it enacted by the Parliament of the Republic of South Africa, section 1 act 57 of the Disaster Management Act, 2002 amended the definition of vulnerability by act 2015 No.16 "vulnerability" defined as the conditions determined by physical, social, economic and environmental factors or processes, which increase the susceptibility of a community to the impact of hazards'. The amendment of the act is in line with the generally accepted definitions used in the international context and across sectors nationally so as to make the principal act simpler and easier to understand (Government Gazette 2015). 
White and Howe (2002) argued that there is a realisation that effective natural hazard prevention and mitigation will need to address not only the hydrological-meteorological factors but also the economic and social factors which influence the greater society and reinforce the impact of hazardous events. Wilhite (2005) stated that social vulnerability to drought is increasing at an alarming rate in many parts of the world and South Africa and O.R. Tambo district is not an exception.

Social vulnerability emerges 'as a concept for understanding what it is about the condition of people that enables a hazard to become a disaster' (Adger 2006; Cutter 2003; Cutter, Boruff \& Shirley 2003; Tapsell et al. 2005). Social vulnerability assessment, therefore, is the process by which the susceptibility of 'elements at risk' to drought hazard is estimated, and includes an analysis of the underlying causes of their vulnerability (Kafle \& Murshed 2006). Dunning and Durden (2011) asserted that social vulnerability assessment defines the association present between social characteristics and vulnerability to drought, delineating the people at risk. Social vulnerability, according to Bogardi and Birkmann (2004), comprises exposure, susceptibility and coping capacity.

A key question to be addressed is whether there is need for the social vulnerability assessment of drought. Tapsell et al. (2010) asked whether there is any gain in such undertakings, because some authors have argued that all people are vulnerable. Indeed, it is just a subset of a full vulnerability assessment in drought risk assessment, but nevertheless very compelling and critical (Dunning \& Durden 2013).

Social vulnerability assessments focus on the social aspects that make some people more vulnerable than others, though exposed to the same drought (Kafle \& Murshed 2006). Some groups of people are more inclined than others to suffer damage or loss from drought. This variability may be influenced by socio-economic characteristics (Jordaan 2014; Kuhlicke et al. 2009; Wisner et al. 2004). Social vulnerability also provides a framework for isolating social causes for drought (Khoshnodifar, Sookhtanlo \& Gholami 2012). Moreover, Birkmann (2006); Cutter et al. (2003); Fekete (2010); King and MacGregor (2000); White and Howe (2002); Wisner et al. (2004); Wongbusarakum and Loper (2011) contended that an analysis of risk management, resilience and adaptation is futile without the understanding of social vulnerability.

The contribution of social factors to vulnerability to drought was not a popular concept in South Africa in general and in O.R. Tambo district of Eastern Cape province in particular. Identifying and assessing the role of social vulnerability in drought risk reduction was a burning and a timely issue considering the current drought situation of South Africa to mitigate and reduce the risk of drought. Although all people living in drought areas are susceptible, the social impacts often mostly affect socially vulnerable people in society. The question is 'Who are the vulnerable to drought in O.R. Tambo district, and what are the social characteristics or systems that make them vulnerable or resilient to drought?' The need to understand these possible vulnerabilities motivated to carrying out this study so as to effectively suggest recommendations on vulnerability reduction measures to the farming community, policy and decision-makers. As defined by the Disaster Management Amendment Act, 2015 (No. 16) vulnerability incorporated physical, economic, environment and social factors that increase the susceptibility of a community to the impact of hazard, in this particular case drought. This study focuses on social aspects of vulnerability; however, it is worth noting that further research is needed to explore the physical, economic and environment aspects.

The main objective of the study was to assess and identify social vulnerability of communal farmers to drought in O.R. Tambo district in the Eastern Cape province. The finding of this result can apply not only from South Africa perspective but also from southern Africa perspective, considering similar socio-economic and demographic characteristics of the population. The research, which is reported in this article, is part of a more comprehensive research project on 'Vulnerability, adaptation and coping with drought: The case of the commercial and subsistence extensive livestock sector in the Eastern Cape' (Water Research Commission [WRC] 2014).

\section{Methodology}

O.R. Tambo district was selected for the study mainly due to the recurring drought events and was reported as one of the most affected district in the Eastern Cape province of South Africa. Moreover, communal farming is the major agricultural practice in the district. The study used a survey data of 87 respondents from August to September 2014 and social vulnerability index (SoVI). Two separate interviews were held to collect data from farmers and extension officers during group discussions. The number of sample size of the study was influenced by the number of communal farmers who attended the workshops as well as their literacy levels.

A purposive sampling method was used to choose the type of respondents. A questionnaire was used to collect demographic data and socio-cultural characteristics of the farmers. In this study, the BBC framework by Bogardi, Birkmann and Cardona (Figure 1) was used to identify variables and interpret results. The term 'BBC' framework comes from the work on previous conceptual models by Bogardi and Birkman (2004) and Cardona (1999, 2001).

Eleven variables were identified for assessment of vulnerability in each household or farm with respect to drought according to the social vulnerability indicators (Table 1). The indicators were rated or classified according to a Likert scale that gave guidance in the estimation of the level of vulnerability: (0-1) very low vulnerability; (1.1-2) low vulnerability; (2-1.3) moderate vulnerability; (3.1-4) high vulnerability and (4.1-5) very high vulnerability.

Equal weights were assigned to indicators to calculate SoVI. Cutter et al. (2003) argued that there is no theoretical 


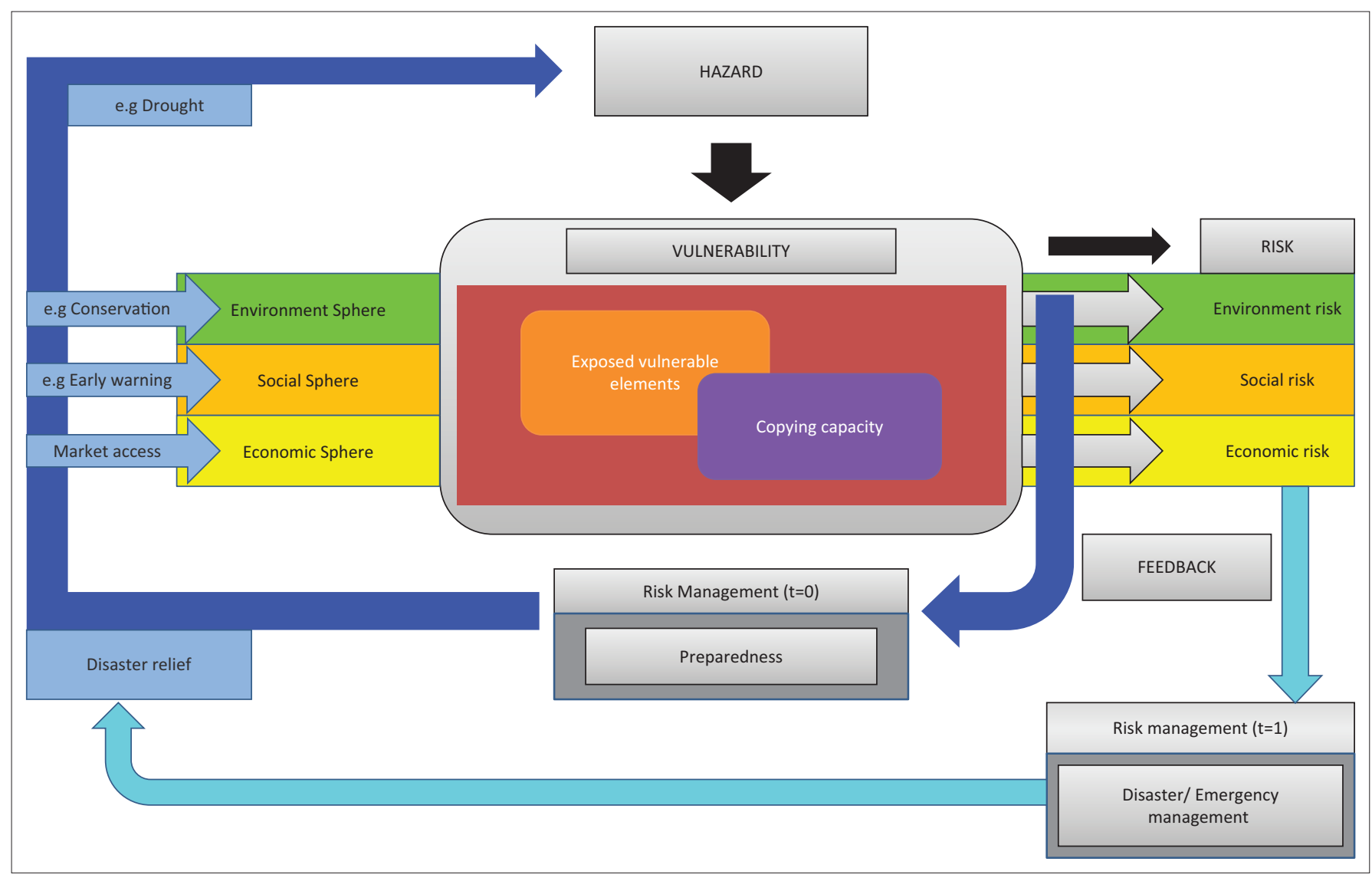

Source: Bogardi and Birkmann (2004); Cardona (1999, 2001)

FIGURE 1: Conceptual framework for vulnerability.

TABLE 1: Selected social vulnerability indicators.

\begin{tabular}{|c|c|c|c|c|}
\hline Indicators (variables) & Measure & Relationship with vulnerability & Source of data & Specification or description \\
\hline Age & Above 60 years & Higher vulnerability & Survey and Stats SA & Number \\
\hline Gender & $\begin{array}{l}\text { Equality in decision-making - } \\
\text { farming activities }\end{array}$ & $\begin{array}{l}\text { Less decision-making - higher } \\
\text { vulnerability }\end{array}$ & Survey & Male or female \\
\hline Social dependence & Dependency ratio & Greater ratio - higher vulnerability & Stats SA & Social grants \\
\hline Education & Formal education & More educated - less vulnerability & Survey and Stats SA & Formal education \\
\hline \multirow[t]{3}{*}{ Culture and practice } & \multirow[t]{3}{*}{ Influence vulnerability } & \multirow[t]{3}{*}{$\begin{array}{l}\text { Stronger cultural practice - greater } \\
\text { vulnerability }\end{array}$} & \multirow[t]{3}{*}{ Survey } & $\begin{array}{l}\text { Hold on to their livestock for honour and status - } \\
\text { their wealth is locked up in their livestock }\end{array}$ \\
\hline & & & & $\begin{array}{l}\text { Women are not allowed to enter an animal kraal- } \\
\text { large numbers of goats are slaughtered for rituals }\end{array}$ \\
\hline & & & & $\begin{array}{l}\text { A person is allowed to burn the veld after attending } \\
\text { a ritual dance }\end{array}$ \\
\hline \multirow[t]{2}{*}{ Security or safety } & \multirow[t]{2}{*}{ Stock theft } & \multirow[t]{2}{*}{$\begin{array}{l}\text { Increasing stock theft - higher } \\
\text { vulnerability }\end{array}$} & \multirow[t]{2}{*}{ Survey } & $\begin{array}{l}\text { Farmers who feel insecure do not invest in their } \\
\text { farming business and usually they suffer more from } \\
\text { adverse drought impacts }\end{array}$ \\
\hline & & & & Stock theft \\
\hline Social networks & Extent & $\begin{array}{l}\text { More involvement in social network - } \\
\text { lower vulnerability }\end{array}$ & Survey & $\begin{array}{l}\text { Farmers' organisations, churches, clubs, stokvels and } \\
\text { family networks }\end{array}$ \\
\hline External support & $\begin{array}{l}\text { Level in drought mitigation and } \\
\text { response }\end{array}$ & $\begin{array}{l}\text { The greater external support - lower } \\
\text { vulnerability }\end{array}$ & Survey & $\begin{array}{l}\text { Government's involvement in drought mitigation and } \\
\text { response, interest in drought, training, funding, } \\
\text { resource and information }\end{array}$ \\
\hline Preparedness strategies & Prepare for drought & $\begin{array}{l}\text { The more prepared - lower } \\
\text { vulnerability }\end{array}$ & Survey & $\begin{array}{l}\text { Availability of drought plans in the community and } \\
\text { preparedness strategies for drought }\end{array}$ \\
\hline Indigenous knowledge & Level & The higher indigenous knowledge & Survey & Traditional and cultural believes \\
\hline
\end{tabular}

rationalisation for assigning different weights to indicate different levels of significance to individual factors' contribution to social vulnerability. The indices were then summed up and divided by the total number of indicators to obtain the SoVI of the district. The SoVI will be calculated using the following mathematical equation:

$$
V^{S O C}=\sum_{i=1}^{11} w_{i}^{s o c} v_{i}^{s o c}
$$$$
V^{S O C} f\left(w_{1}^{s o c} v_{1}^{s o c}, w_{2}^{s o c} v_{2}^{s o c}, w_{3}^{s o c} v_{3}^{s o c}, \ldots \ldots \ldots w_{11}^{s o c} v_{11}^{s o c}\right),
$$ 
where: $v_{1}^{\text {soc }}=$ age, $v_{2}^{\text {soc }}=$ gender participation, $v_{3}^{\text {soc }}=$ psychological stress, $v_{4}^{\text {soc }}=$ social dependence, $v_{5}^{\text {soc }}=$ education level, $v_{6}^{s o c}=$ cultural values and practices, $v_{7}^{s o c}=$ security or safety, $v_{8}^{s o c}=$ social networks, $v_{9}^{\text {soc }}=$ external support, $v_{10}^{\text {soc }}=$ preparedness strategies, $v_{11}^{s o c}=$ indigenous knowledge, $w_{1}^{s o c}=$ equal weighting factor for all variables.

\section{Result and discussion Socio-economic characteristics of respondents}

The respondents' median age was 52 years above the national black South African median age of 24 years (StatsSA 2012), and the average age of 51 years shows that the younger generation was not involved in agricultural activities. The average farming experience was 13 years, although experience gained with age, farming need not be dominated by aged populations in any region, as this could have negative implications on the future of food production (Carino 2013). This study revealed that more men were involved in farming than women, with $71 \%$ of the respondents being men and 29\% women. Khoshnodifar et al. (2012) found that wheat farmers in Mashhad County, Iran, were $84.5 \%$ men and $15.5 \%$ women.

The greater proportion of the respondents were married (74\%), and widows (8\%) comprise a very vulnerable group (Cutter et al. 2009) and may be more susceptible to drought impacts. Among the respondents, $26 \%$ did not have any schooling at all, which is higher than the district's $17.3 \%$ illiteracy rate (StatsSA 2012).

Most farmers in this study practiced livestock farming, confirming that the Eastern Cape province is indeed a livestock farming region (ECDC 2014). The major categories of livestock they farm were cattle, sheep and goat. Most farmers lost their livestock through death, whereas some sold a portion to reduce their herd. There were reports of farmers who delayed in selling their livestock in preparation for imminent drought. Consequently, they later sold when their livestock could not fetch a good price. They had lost weight owing to poor quality and reduced quantity of feed as a result of dry conditions. One farmer reported that he increased his livestock during drought because he would buy them at reduced prices from other farmers.

\section{Social indicators of vulnerability to drought}

Table 2 presents a summary of social indicators and their contributions to social vulnerability to drought. The results of the social vulnerability assessment of communal farmers to drought in the O.R. Tambo district municipality indicate a very high vulnerability score of 4.1 (Table 2). Out of 11 indicators, 6 indicators, namely, psychological stress, social dependence, cultural values and practices, security, social networks and preparedness strategies, contributed more significantly to social vulnerability to drought in O.R. Tambo district. These variables all scored 5 in the
TABLE 2: Estimation of social vulnerability index to drought in O.R. Tambo district.

\begin{tabular}{|c|c|c|c|}
\hline Social Indicator & Findings & Index & Vulnerability \\
\hline Age & $23 \% \geq 60$ years & 3 & Moderate \\
\hline Gender participation & $\begin{array}{l}62 \% \text { responded gender affects } \\
\text { agriculture-related decision- } \\
\text { making }\end{array}$ & 4 & High \\
\hline Psychological stress & $\begin{array}{l}79 \% \text { responded stress influences } \\
\text { vulnerability }\end{array}$ & 5 & Very high \\
\hline Social dependence & $81 \%$ dependency ratio & 5 & Very high \\
\hline Education levels & $74 \% \geq$ high school qualification & 2 & Low \\
\hline $\begin{array}{l}\text { Cultural values and } \\
\text { practices }\end{array}$ & $\begin{array}{l}90 \% \text { said cultural practices } \\
\text { influence vulnerability }\end{array}$ & 5 & Very high \\
\hline Security or safety & $\begin{array}{l}\text { There was } 25 \% \text { increase in stock } \\
\text { theft during drought }\end{array}$ & 5 & Very high \\
\hline Social networks & $\begin{array}{l}18 \% \text { responded social networks } \\
\text { are involved in drought risk } \\
\text { reduction }\end{array}$ & 5 & Very high \\
\hline External support & $\begin{array}{l}22 \% \text { responded government is } \\
\text { involved in drought risk reduction }\end{array}$ & 4 & High \\
\hline $\begin{array}{l}\text { Preparedness } \\
\text { strategies }\end{array}$ & $\begin{array}{l}9 \% \text { indicated they prepare for } \\
\text { drought }\end{array}$ & 5 & Very high \\
\hline $\begin{array}{l}\text { Indigenous } \\
\text { knowledge }\end{array}$ & $\begin{array}{l}64 \% \text { claimed to have indigenous } \\
\text { knowledge on farming }\end{array}$ & 2 & $\begin{array}{l}\text { Low } \\
\text { vulnerability }\end{array}$ \\
\hline Total score & - & 45 & - \\
\hline $\begin{array}{l}\text { SoVI (total score } \div \\
\text { no. of variables): } \\
45 \div 11=4.1\end{array}$ & - & - & Very high \\
\hline
\end{tabular}

vulnerability measurement, which is rated as very high vulnerability.

Gender and external support contribute highly to the social vulnerability of communal farmers to drought in O.R. Tambo district, which scored a 4 . The huge imbalance in decisionmaking related to drought risk reduction influences social vulnerability to a great extent. The impacts affected the female gender, which is disadvantaged in decision-making, and also the whole farming enterprise. Livestock farming suffers more from lack of decision-making powers by women than crop farming does. This indicator is closely related to the cultural values and practices indicator, which was estimated at an index of 5, which is very high vulnerability. Women, according to tradition, cannot make decisions about reducing livestock, even if there is impending drought. Moreover, it was reported that they cannot enter a kraal because the cows will not reproduce. The cultural values and practices were also associated with the pride that Xhosa men have in their large livestock herds, which they will not easily reduce in preparation for an impending drought.

Age scored a 3. However, education level and indigenous knowledge scored low on vulnerability; hence, they are positively contributing to resilience to drought impacts. These two variables both scored 2 in the estimation of vulnerability, which is low vulnerability on the SoVI.

The result indicates that farmers perceived government's involvement in drought risk reduction was below expectation, which was reiterated by extension officers. These findings coincide with other studies that revealed government as being limited in its involvement in drought risk reduction (Hassen 2008; Jordaan 2012; Ngaka 2012). The farmers indicated that the training programmes conducted by the extension officers 
in O.R. Tambo district do not focus on drought risk reduction, but on farming in general. There is no drought awareness or drought early warning issued to the farmers until the drought is already in progress. External support, therefore, contributes very little in helping farmers reduce their vulnerability to drought.

Social networks and preparedness strategies were initially considered under coping capacity. However, farmers are extremely exposed to drought impacts because they do not have any strategies to prepare for drought, neither do they have support from their social networks; hence, their coping capacity is severely undermined. The extension officers attributed the lack of involvement of social networks in drought issues to mere ignorance of their potential role. Generally, both the extension officers and farmers were surprised to learn that the involvement of clubs, churches and other community organisations in drought issues would increase the community's resilience to its impacts. Kuhlicke et al. (2011) revealed that community networks and preparedness strategies were important factors in reducing social vulnerability to flooding.

The absence of operational and effective farmers' association in the study area poses a challenge to farmers' preparation and response to drought. The respondents argued that the associations operate at the top level. At the grassroots level, where the farmers need the support, they were said to be mostly absent or ineffective. Ntinga O.R. Tambo Development Agency (2014) confirms that sheep farming was well established in the communal farming areas of the O.R. Tambo district, although they need to be more organised in order to co-ordinate programmes in their communities. The Wool Growers' Association solely depends on them. The contribution of lack of effective farmers' institutions to vulnerability to drought was highlighted by Iglesias, Moneo and Quiroga (2007) who argued that participation of farmers in local institutions will lead to reduced vulnerability to drought.

Psychological stress contributes to a very high vulnerability situation. Although it is impossible to deduce from this study the reason why such a large proportion of the respondents held this perception, the issue of stress needs attention. As reported by Connor (2014), stress has been termed 'the number one killer' in the United States, and in this study, stress has been shown to contribute greatly to social vulnerability to drought. On 29 December 2015, in the Eastern Cape province of South Africa, one farmer, aged 34, a commercial cattle farmer, took his own life as the consequences of the worst drought had simply become too much for him (Chabalala 2016).

Dependence on government for social grants is very high in O.R. Tambo district (StatsSA 2012), and this increases farmers' vulnerability to drought. Because drought mitigation is still more response-based than risk-reductionbased, farmers depend on government for assistance during and after drought. Dependency on social grants already

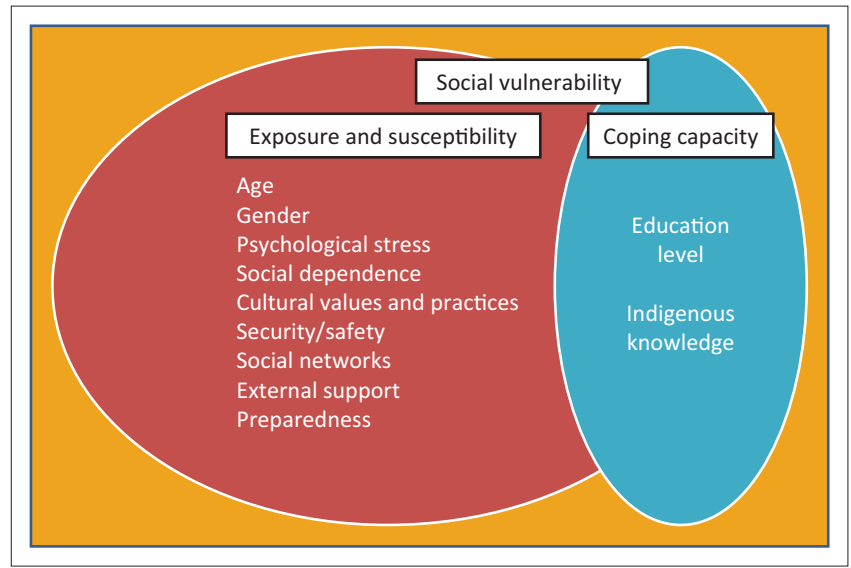

FIGURE 2: Summary of indicators using the BBC conceptual framework.

indicates marginalisation and poverty (Adger et al. 2004), hence the inability to cope and recover from drought. It was argued that the dependency on social grants has created a dependency syndrome among locals.

The level of education, which was expected to contribute more to social vulnerability to drought in the O.R. Tambo district because of the district's high illiteracy level, did not score high on the SoVI. Instead, education had a low vulnerability. The study revealed that the respondents perceived indigenous knowledge as contributing to the slight resiliency the farmers have towards drought. It has been argued that there is no community that is completely vulnerable (Adger et al. 2004; Birkmann 2006). The use of indigenous knowledge is relevant to a rural community that has high illiteracy levels. Where they cannot access information owing to illiteracy, indigenous agricultural knowledge will help them to cope with drought. This corroborates what UNEP (2008) claimed: indigenous knowledge is still integral among most African local or indigenous communities. The older people use indigenous knowledge to reduce the impact of disasters.

Figure 2 presents the different identified social indicators and their contribution to social vulnerability to drought. It is an extraction of the vulnerability segment from the BBC model showing the interaction of the components of vulnerability, exposure, susceptibility and coping capacity (Birkmann 2006). Indeed, this study, as argued by Fekete (2010), shows that no community is totally vulnerable. Whereas all indicators identified contributed to social vulnerability to drought in the study area, indigenous knowledge and education level fell within the coping capacity component, thereby contributing towards resilience to drought.

\section{Conclusion and recommendations}

This study was undertaken to assess and identify the social vulnerability to drought of communal farmers in O.R Tambo district in the Eastern Cape province of South Africa using a survey data and SoVI. The result found that social vulnerability of communal farmers to drought in O.R. Tambo district is very high. Factors such as psychological 
stress, cultural values and practices, social dependence, lack of security, social networks and lack of preparedness strategies were the major contributors to social vulnerability to drought.

Government's limited involvement in drought risk reduction, the age of the farmers and the imbalance of decision-making powers between the men and women also contributed to social vulnerability to drought. The cultural values and practices closely influenced gender dynamics. Based on the study, the following recommendations were drawn:

- A national policy on drought risk reduction should be developed for guidance. When drought occurs, it usually affects more districts or provinces. Therefore, a national policy on drought risk reduction should be developed which will guide provinces and district municipalities. The national policy should engage key role player for coordination and collaboration. There should be coordination among monitoring agencies in terms of reliable early warning data, communicated in a comprehensible way to decision-makers, effective farmer's organisations (National African farmers union of South Africa and African Farmers Association of South Africa), Agri SA and private sectors. Collaboration with government departments at national and provincial level should also be strengthened. This includes collaboration with the Department of Agriculture, Forestry and Fisheries (DAFF) at national level, provincial Departments of Agriculture, NDMC and Provincial Disaster Management Centres (PDMC). Additionally, the provincial departments such as Provincial DAFF and PDMC should budget for risk reduction activities.

- Local representatives from farmers and extension services should participate in planning and implementing the drought plan.

- The DAFF should include programmes, which address drought mitigation (such as warning and preparedness) for guidance extension services. This could be achieved with the commitment, trust, devotion and willingness of main key player including politician, monitoring agencies, farmers' organisation, private sectors, National and Provincial DAFF, NDMC and PDMC to take responsibility to implement drought policies and work efficiently towards achieving minimal drought impact.

- The security of livestock should be improved through the building and repairing of fences, as well as the reintroduction of rangers in the district. Security is a challenge for all communal farmers. Stock theft is a big problem, and communal land adjacent to the Lesotho border is particularly vulnerable - this is attributed by old fences. The study suggested that for the maintenance of old infrastructure such as fences, an infrastructure subsidy scheme should be provided as an initiative to build drought resilience by DAFF. Besides, as highlighted by the Minister of Department of Agriculture, Forestry and Fisheries of South Africa in 2015, in Annual Congress of National Wool Growers' Association, 'the South African merino develop the landrace breed
(Dohne merino) - added versatility to the wool sheep gene pool and broadening the potential impact and range of the South Africa - need to continue intensively and expand in large scale'.

- The indigenous knowledge in the O.R. Tambo district should be compiled, documented and published for the young generation guidance.

\section{Acknowledgements}

The authors thank the WRC and DAFF for their support and funding for this project. 'Vulnerability, adaptation and coping with drought: The case of the commercial and subsistence extensive livestock sector in the Eastern Cape' (KSA4/Thrust 4/P2-Contract No. 2280).

\section{Competing interests}

The authors declare that they have no financial or personal relationships that may have inappropriately influenced them in writing this article.

\section{Authors' contributions}

F.M. was the main researcher on this study; she conceptualised and drew up the framework of the article, performed a quantitative analysis and wrote some part of the manuscript; A.J.J. was the supervisor of F.M. and contributed to the review of conceptual framework and quantitative analysis and wrote some part of the manuscript. Y.T.B. reviewed the overall content of the manuscript, incorporated some important policy implications of the study and re-wrote the manuscript.

\section{References}

Adger, W.N., 2006, 'Vulnerability', Global Environmental Change 16(3), 268-281. https://dx.doi.org/10.1016/j.gloenvcha.2006.02.006

Adger, W.N., Brooks, N., Bentham, G., Agnew, M. \& Eriksen, S., 2004, New indicators of vulnerability and adaptive capacity, Technical Report 7, Tyndall Centre for Climate Change Research, Norwich.

Agri SA, 2016, A rain drop in the drought. Report to the multi-Stakeholder task team on the drought, Agri SA's status report on the current drought crisis, viewed 03 March 2016, from http://www.nstf.org.za/wp-content/uploads/2016/06/Agri-SADrought-Report_CS4.pdf

Bahta, Y.T., Jordaan, A. \& Muyambo, F., 2016, 'Communal Farmers' perception of drought in South Africa: Policy implication for drought risk reduction', International Journa of Disaster Risk Reduction 20, 39-50. http://dx.doi.org/10.1016/j.ijdrr.2016.10.007

Birkmann, J., 2006, 'Measuring vulnerability to promote disaster-resilient societies: Conceptual frameworks and definitions', in J. Birkmann (ed.), Measuring vulnerability to natural hazards: Towards disaster resilient societies, pp. 9-54, United University Press, New York.

Bogardi, J.J. \& Birkmann, J., 2004, 'Vulnerability assessment: The first step towards sustainable risk reduction', in D. Malzahn \& T. Plapp (eds.), Disasters and societyFrom hazard assessment to risk reduction, pp. 75-82, Logos Verlag Berlin, Berlin.

Cardona, O.D., 1999, 'Environmental management and disaster prevention: Two related topics: A holistic risk assessment and management approach', in J. Ingleton (ed.), Natural disaster management, Tudor Rose, London.

Cardona, O.D., 2001, ‘Estimación Holística del Riesgo Sísmico Utilizando Sistemas Dinámicos Comple', Technical University of Catalonia, Barcelona.

Carino, C.M., 2013, Aging Filipino farmers to affect food security, the Manila Times, viewed 25 November 2015, from http://www.manilatimes.net/aging-filipinofarmers-to-affect-food-security/12166/

Chabalala, J., 2016, Drought: Farmers commits suicide a day before rain falls, viewed 09 January 2016, from http://www.news24.com/SouthAfrica/News/droughtfarmer-commits-suicide-a-day-before-rain-falls-20160101

Connor, T., 2014, Stress is the number one killer today, viewed 21 September 2015, from http://www.myarticlearchive.com/articles/6/214.htm

Cutter, S.L., 2003, 'The vulnerability of science and the science of vulnerability', Annals of the Association of American Geographers 93(1), 1-12. https://dx.doi. org/10.1111/1467-8306.93101 
Cutter, S.L., Boruff, B.J. \& Shirley, L.W., 2003, 'Social vulnerability to environmental hazards', Social Science Quarterly 84(2), 242-261. https://dx.doi. hazards', Social Science Quar
$\mathrm{org} / 10.1111 / 1540-6237.8402002$

Cutter, S.L., Emrich, C.T., Webb, J.J. \& Morath, D., 2009, Social vulnerability to climate variability hazards: A review of the literature, Hazards and Vulnerability Research Institute, Department of Geography, University of South Carolina, Columbia.

Department of Rural Development and Land Reform (DRDLR), 2013, Climate change risk and vulnerability assessment for rural human settlements, Department of Rural Development and Land Reform, Pretoria, South Africa.

Dunning, C.M. \& Durden, S., 2011, Social vulnerability analysis methods for Corps planning, Report 2011-R-07, U.S. Army Corps of Engineers, Institute for Wate Resources, Alexandria, VA.

Dunning, C.M. \& Durden, S., 2013, Social vulnerability analysis: A comparison of tools, IWR White Paper: US Army Corps of Engineers, Institute for Water Resources, Alexandria, VA.

Eastern Cape Development Cooperation (ECDC), 2014, Agriculture, viewed 03 August 2014, from http://www.ecdc.co.za/ecdc/opportunities/agriculture_and_minerals

Food and Agriculture Organization (FAO), 2013, Drought, viewed 16 October 2015, from http://www.fao.org/docrep/017/aq191e/aq191e.pdf

Fekete, A., 2010, 'Assessment of social vulnerability for river-floods in Germany', Doctoral thesis, University of Bonn.

Government Gazette, 2015, Act No.16 of 2015: Disaster management Amendment Act, 2015, Government Gazette of Republic of South Africa, Cape Town.

Gumenge, P., 2010, 'Eastern Cape reels as drought persists', Grocotts Mail, viewed 18 September 2015, from http://www.grocotts.co.za/content/eastern-cape-reelsdrought-persists-19-01-2010

Hassen, A., 2008, 'Vulnerability to drought risk and famine: Local responses and external interventions among the Afar of Ethiopia, a study on the Aghini Pastoral Community', Doctoral thesis, University of Bayreuth.

Iglesias, A., Moneo, M. \& Quiroga, S., 2007, 'Methods for evaluating social vulnerability to drought', Options Méditerranéennes Series B 58, 129-133.

International Strategy for Disaster Reduction (UNISDR), 2005, Drought, living with risk: An integrated approach to reducing societal vulnerability to drought. ISDR Ad Hoc Discussion Group on Drought, viewed 19 October 2015, from http://www. unisdr.org/2005/task-force/tf-meetigns/7th\%20TF\%20mtg/tmp/Drought_ information report.pd

IRIN News, 2004, South Africa: Drought emergency in six provinces affects 4 million viewed 18 September 2015, from http://www.IRINNEWSNEWSnews.org/ report/48149/south-africa-drought-emergency-in-six-provinces-affects-4-million

Jordaan, A., 2014, Karamoja, Uganda drought risk assessment: Is drought to blame for chronic food insecurity?, International Rescue Committee, Kampala, Uganda.

Jordaan, A.J., 2012, 'Drought risk reduction in the Northern Cape Province, South Africa', PhD Thesis, University of the Free State, Bloemfontein, South Africa.

Kafle, S.K. \& Murshed, Z., 2006, Community-based disaster risk management for local authorities, viewed 28 September 2015, from http://www.adpc.net/ pdrsea/pubs/curriculum-cbdrm.pdf

Khoshnodifar, Z., Sookhtanlo, M. \& Gholami, H., 2012, 'Identification and measurement of indicators of drought vulnerability among wheat farmers in Mashhad County, Iran', Annals of Biological Research 3(9), 4593-4600.

King, D. \& Macgregor, C., 2000, 'Using social indicators to measure community vulnerability to natural hazards', Australia Journal of Emergency Management 15(3), 52-57.
Kuhlicke, C., Scolobig, A., Tapsell, S., Steinführer, A. \& De Marchi, B., 2009, 'Contextualizing social vulnerability: Findings from case studies across Europe', "Natural Hazards 58, 789-810. https://dx.doi.org/10.1007/s11069-011-9751-6

Kuhlicke, C., Steinführer, A., Begg, C., Bianchizza, C., Bründl, M., Buchecker, M. et al., 2011, 'Perspectives on social capacity building for natural hazards: outlining an emerging field of research and practice in Europe', Environmental Science and Policy 14(7), 804-814.

National Disaster Management Centre (NDMC), 2016, Sustainable livelihoods for poverty and disaster risk reduction, viewed 10 November 2016, from http://www. preventionweb.net/search/pw\#query=Eastern+Cape+province++declared+as+di saster+areas+by+National+Disaster+Management+Centre+\&hits=20\&sortby=def ault\&view=pw

Ngaka, M.J., 2012, 'Drought preparedness, impact and response: A case of the Eastern Cape and Free State provinces of South Africa', Jamba: Journal of Disaster Risk Studies 4(1), 1-10. https://dx.doi.org/10.4102/jamba.v4i1.47

Ntinga OR Tambo Development Agency, 2014, Sheep Production, viewed 28 November 2015, from http://ntinga.org.za/index.php?option=com_content\&view=article\& id $=76 \&$ Itemid $=69$

South Africa, Statistics (StatsSA), 2012, Census 2011 Municipal report: Eastern Cape, Report No. 03-01-50, Pretoria, South Africa, viewed 28 February 2016, from http://www.statssa.gov.za/census/census_2011/census_products/EC_ Municipal_Report.pdf

South African Broadcasting Corporation (SABC), 2016, Agri SA calls for a nationa disaster declaration, viewed 08 November 2016, from http://www.sabc.co.za/ news/a/6fb5ed804d15a0b2a2b4e293fd523eaa/Agri-SA-calls-for-a-nationaldisaster-declaration-20161006

Tapsell, S., McCarthy, S., Faulkner, H. \& Alexander, M., 2010, Social vulnerability to natural hazards, University of London, Flood Hazard Research Centre, Middlesex.

Tapsell, S.M., Tunstall, S.M., Green, C. \& Fernande, Z.A., 2005, Social indicator set, Flood site report T11-07-01, Flood Hazard Research Centre, Middlesex University, Enfield.

The Southern Times, 2016, El Niño weather- a result of climate or variability?, viewed 09 November 2016, from http://southernafrican.news/2016/06/10/el-ninoweather-a-result-of-climate-change-or-variability/

United Nations Environment Programme (UNEP), 2008, Indigenous knowledge in disaster management in Africa, Nairobi, Kenya, viewed 10 March 2016, from http://www. icsu.org/icsu-africa/news-centre/news/Appendix9IndigenousBookletUNEP.pdf

Water Research Commission (WRC), 2014, Water utilization in agriculture, Water Research Commission knowledge review 2013/2014.

White, I. \& Howe, J., 2002, 'Policy and practice - Flooding and the role of planning in England and Wales: A critical review', Journal of Environmental Planning and Management45(5), 735-745. https://dx.doi.org/10.1080/0964056022000013093

Wilhite, D.A., 2005, Drought and water crises: Science, technology and management issues, CRC Press, Boca Raton, FL.

Wisner, B., Blaikie, P., Cannon, T. \& Davis, I., 2004, 'At risk: Natural hazards, people's vulnerability and disasters', 2nd edn., Routledge, London.

Wongbusarakum, S. \& Loper, C., 2011, Indicators to assess community- level social vulnerability to climate change: An addendum to SocMon and SEM-Pasifika regional socioeconomic monitoring guidelines, First draft for public circulation and field testing, viewed 26 March 2016, from https://www.google.co.za/url?sa=t\&rc $t=j \& q=\& e s r c=s \&$ source=web\& $c d=1 \& c a d=r j \& u a c t=8 \& v e d=0$ ahUKEwiVurDTObTQ AhWIIsAKHUZkDiwQFggZMAA\&url=http $\% 3 A \% 2 \mathrm{~F} \% 2 \mathrm{Fwww}$. socmon. org\%2Fdownload.ashx\%3Fdocid\%3D64623\&usg=AFQjCNE19-8FhTbRHeeHUnB HjVAUZxTfAg\&bvm=bv.139250283,d.d2s 